\title{
Historical Economics of Wars in the 20th Century
}

\author{
By Jochen Streb (Mannheim) and Tamás Vonyó (London)
}

This year is the hundredth anniversary of the outbreak of the First World War. It might be therefore surprising that in a volume that deals with the historical economics of wars only one out of seven articles focuses on the analysis of the First World War, while the others concentrate on the period during and after the Second World War. ${ }^{1}$ However, this is not a coincidence. As Dieter Ziegler recently stressed at a meeting of the Gesellschaft für Unternehmensgeschichte, ${ }^{2}$ the history of the First World War was rather neglected both by economic and business historians in the last decade. Arguably the last major contribution dates back to 2005 when Stephen Broadberry and Mark Harrison edited their volume on the economics of the First World War. ${ }^{3}$

In this introduction, we want to revive interest in the economic history of the First World War (and other major wars) by advocating three promising strategies for future research on the historical economics of wars in the 20th century. We take a stronger focus, first, on international comparisons, second, on inter-temporal comparisons, and, third, on the economic and social consequences of wars.

Various internationally comparative studies of the Second World War have already demonstrated that the rearmament preparations and the war economies of the combatants were generally far more similar than was realised at the time and many scholars had often suggested. The extent of the similarities might even imply the existence of an international model of a modern war economy constructed around the commonly-held characteristics of the different national economies. First of all, there are many similarities at the macroeconomic level. In this respect, Mark Harrison's volume on the economics of Second World War offers a comprehensive framework for discussion. ${ }^{4}$ Many countries witnessed a dramatic rise of military spending on the eve of and during the Second World War; this led to a sharp decline in private consumption (usually enforced by price controls and rationing). Expenditure was often financed by money creation and also, on the part of the Axis powers, by exploiting the resources of occupied countries and appropriating the assets of minorities such as the Jews. This rise in military spending triggered a rapid and unexpected increase in armament production which, in more than one country, was christened an armament miracle or a

1 Preliminary versions of most of these articles were presented and discussed in sessions at the European Social Science History Conference in Glasgow, Scotland (April 2012), and the XVIth World Economic History Congress in Stellenbosch, South Africa (July 2012).

2 36. Wissenschaftliches Symposium der Gesellschaft für Unternehmensgeschichte: Unternehmen und Krieg: Neuere Studien zum Ersten Weltkrieg, Mannheim, Germany, October 2013.

3 See S. Broadberry/M. Harrison (Eds.), The Economics of World War I, Cambridge 2005. See also $S$. van de Kerkhof, Von der Friedens- zur Kriegswirtschaft: Unternehmensstrategien der deutschen Eisenund Stahlindustrie vom Kaiserreich bis zum Ende des Ersten Weltkriegs, Essen 2006; H. Wixforth, Die Gründung und Finanzierung von Kriegsgesellschaften während des Ersten Weltkriegs, in: H. Berghoff/J. Kocka/D. Ziegler (Eds.), Wirtschaft im Zeitalter der Extreme. Im Gedenken an Gerald D. Feldman, Munich 2010, pp. 81-105.

4 See M. Harrison (Ed.), The Economics of World War II: Six great powers in international comparison, Cambridge 1998. 
production miracle. Most combatants' war economies depended heavily on the import of raw materials and vital armament goods. Given the vulnerability of foreign trade during wartime, the availability of domestic strategic resources was therefore decisive for the outcome of the war. In addition, considerable short-run adjustment costs were incurred when plants producing consumption goods were converted to ones producing armaments. ${ }^{5}$

Even more striking than any similarities at the macroeconomic level, is what can be said about the relationship between industry and government in national economies. For, notwithstanding the obvious ideological differences between states, many similarities clearly existed at the level of implementing and operationalizing armament policies. This implies that the Allied democracies used, by and large, the same means as the Axis dictatorships to foster armament production. All governments procuring weapons and other goods from private firms had to deal with the trade-off between increasing efficiency when using fixedprice contracts and decreasing excess profits and transaction costs when deploying cost-plus contracts. ${ }^{6}$ What is more, given the overheated boom of the war economies most governments had to rely on bilateral negotiations with single armament manufacturers instead of using competitive bidding to award contracts.

Finally, there are several similarities at the microeconomic level of armament firms. Of particular interest are studies that have looked at how production was organised. Analysing the data of 22 different aircraft types produced by American industry during World War II, Alchian was the first post-war economist to observe that the direct amount of labour required for producing a unit of a special aircraft type regularly declined when the total output of this type was expanded. ${ }^{7}$ It appears that worker efficiency increases more frequently where a particular task is repeated. Reviewing the wartime output of B-17s from Boeing's Plant No. 2 in Seattle, Washington, Mishina noticed that management learned how to increase worker productivity by improving the production system in the course of the manufacturing process. ${ }^{8}$ These improvements included the implementation of just-in-time production to clear the shop floor of stocks that were not necessary for current production runs, and the breakdown of the assembly process into finer sub-assemblies which increased the division of labour. Learning-by-doing by blue-collar and white-collar workers occurred in all kinds of industries, but the resulting increase in labour productivity was especially high when workers

5 To replace male workers drafted into the armed services, governments tried to increase the industrial employment of women. US publicity campaigns idealised workers such as 'Rosie the Riveter', and women became also increasingly important in Germany's labour force even though Nazi propaganda exalted women's domestic roles.

6 See, for example, J. Streb, Can Politicians Speed Up Long-Term Technological Change? Some Insights from a Comparison of the German and US-American Synthetic Rubber Programs Before, During and After World War II, in: Essays in Economic and Business History 21, 2003, pp. 33-49; J. Streb, Negotiating Contract Type and Contract Clauses in the German Construction Industry during the Third Reich, in: RAND Journal of Economics 40, 2009, pp. 364-379.

7 See A. Alchian, Reliability of Progress Curves in Airframe Production, in: Econometrica 31, 1993, pp. 679-693.

8 See K. Mishina, Learning by New Experiences: Revisiting the Flying Fortress Learning Curve, in: N.R. Lamoreaux/D.M.G. Raff/P. Temin (Eds.), Learning by Doing in Markets, Firms and Countries, Chicago 1999, pp. 145-184. International evidence for continuous cost reductions in the production of various armament goods is presented in M. Harrison, Accounting for War: Soviet Production, Employment, and the Defence Burden, 1940-1945, Cambridge 1996, pp. 225, 231. 
were given rather complex tasks - as was the case in the aircraft industry. Budraß, Scherner and Streb have reached the same conclusion for the German aircraft industry during the Second World War. ${ }^{9}$ In addition, their research confirms that there was a dramatic increase in inter-firm division of labour in the German aircraft industry. This allowed both the finalassembly manufacturer and the component suppliers to concentrate on their respective core competences and, thereby, economies of scale to be realised. ${ }^{10}$ Tetsuji Okazaki also claims that outsourcing production by expanding supplier networks was the most important reason for the miraculous acceleration of aircraft production in the Japanese war economy. ${ }^{11}$

International comparability has also been suggested by recent econometric investigations into the lasting effect of wartime activities. We want to stress two findings. First, the analysis of the effects of strategic bombing on long-term city growth has shown similar results in the cases of Japan and Germany. ${ }^{12}$ Second, the lasting impact of the Second World War on the geography of economic activity has been demonstrated by Cullen and Fishback for the United States and by Vonyó for West Germany. ${ }^{13}$ These studies made notable contributions to a fast-growing international literature of historical economic geography.

In this volume, three articles have a strong international perspective. Eric Golson quantifies Swiss foreign trade balances with both the Axis powers and the Allies during the Second World War. To preserve neutrality Swiss trade policy had to give both sides the impression that it complied with its particular demands. As a result, in trade with Germany, Switzerland realized positive net imports which were only partly offset by improving terms of trade while it exported more goods to the Allies than were imported from them. It is interesting to note that even though Germany would have been able to finance its imports from Switzerland with the currency earned by its exports to this country, Switzerland agreed on providing a large clearing credit which enabled Germany to use the Swiss franc for imports from third party countries. Johann Custodis examines the economic effects of the employment of German and Italian prisoners of war during and after the Second World War in Britain and her dominions. At the peak, this particular workforce contributed about one per cent to British GDP. It was especially in agriculture (and the Canadian lumber industry) where German POWs played a significant role in overcoming severe labour shortage. Neil Forbes provides an explicit

9 See L. Budraß/J. Scherner/J. Streb, Fixed-price Contracts, Learning and Outsourcing: Explaining the Continuous Growth of Output and Labour Productivity in the German Aircraft Industry during World War II, in: Economic History Review 63, 2010, pp. 107-136.

10 See also J. Scherner/J. Streb/S. Tilly, Supplier Networks in the German Aircraft Industry during World War II and their Long-term Effects on West Germany's Automobile Industry during the 'Wirtschaftswunder', forthcoming in: Business History; J. Fear, Die Rüstungsindustrie im Gau Schwaben 19391945, in: Vierteljahrshefte für Zeitgeschichte 35, 1987, pp. 193-216.

11 See T. Okazaki, The Supplier Networks and Aircraft Production in Wartime Japan, in: Economic History Review 64, 2011, pp. 973-994.

12 D.R. Davis/D.E. Weinstein, Bones, Bombs and Breakpoints: The Geography of Economic Activity, in: American Economic Review 92, 2002, pp. 1269-1289; S. Brakman/H. Garresten/M. Schramm, The Strategic Bombing of German Cities during World War II and its Impact on City Growth, in: Journal of Economic Geography 4, 2004, pp. 201-218.

13 P. Fishback/J. Cullen, Second World War Spending and Local Economic Activity in U.S. Counties, 1939-1958, in: Economic History Review 66, 2013, pp. 975-992; T. Vonyó, The Bombing of Germany: The Economic Geography of War-Induced Dislocation in West German Industry, in: European Review of Economic History 16, 2012, pp. 97-118. 
comparison of the shadow factory schemes in Britain and Germany in the late 1930s. In both countries, governments were forced to finance many additional armament factories because private firms were not willing to shoulder the risk of investing in what they assumed would become excess capacity following the war and, consequently, of little value. Geo-strategic considerations often determined the location of new plants and led to a geographical reallocation of labour.

The international similarities of both the armament policies of governments and the microeconomic changes within firms suggest that it might be misleading to make a strong distinction between the market-oriented war economies of the Western Allies and the centrally-planned war economies of Russia and the Axis powers. Instead, it should be rather assumed that the requirements of fighting a material-intensive, global conflict led all parties to build up the same type of modern war economy, heavily dependent upon state intervention, despite insurmountable ideological differences. ${ }^{14}$

With respect to the inter-temporal comparison of war economies a recent contribution by Hugh Rockoff sets a new standard. ${ }^{15}$ Based on a list of general research criteria like the economic causes and legacies, the means of financing and mobilizing resources, or the economic and social costs of wars, Rockoff identifies the commonalities and differences of all major wars America has waged since the end of the 19th century. Also for the German case, an inter-temporal comparison of war-related problems and approaches to solve them might lead to new insights. For example, it would be interesting to analyze in detail how the experiences of the First World War influenced Germany's preparation for the Second World War. From a methodological perspective it seems particularly promising to use the new theoretical concepts and quantitative methods that were successfully applied in examining the war economies of the Second World War also in research projects on the economics of the First World War. In this volume, Tobias Jopp provides an example for this approach. Economic historians have often relied on capital market data to learn, with the help of event studies, more about contemporary expectations about the future course of a war. ${ }^{16}$ By analyzing the development of prices for the German imperial loan at the Amsterdam stock market between 1915 and 1919, Jopp comes to the new result that the British conscription controversy of January 1916, which signaled Britain's willingness to commit herself to a full-scale war effort, undermined investors' confidence in Germany's ability to win the war (and pay back her debts) significantly and permanently at this early stage.

Most studies on the economic history of wars concentrate on the problems of the macroeconomic transition from a market-oriented peacetime economy to a more centrally-controlled war economy. In contrast, the long-term economic and social consequences of wars are often neglected. A notable exception to this rule is the ongoing discussion about whether a nation's

14 See J. Streb, Das nationalsozialistische Wirtschaftssystem: Indirekter Sozialismus, gelenkte Marktwirtschaft oder vorgezogene Kriegswirtschaft, in: W. Plumpe/J. Scholtyseck (Eds.), Der Staat und die Ordnung der Wirtschaft. Vom Kaiserreich bis zur Berliner Republik, Stuttgart 2012, pp. 61-83.

15 See H. Rockoff, America's Economic Way of War: War and the US Economy from the SpanishAmerican War to the Persian Gulf War, Cambridge 2012.

16 See, for example, K.L. Willard/T.W. Guinnane/H. Rosen, Turning Points in the Civil War: Views from the Greenback Market, in: American Economic Review 86, 1996, pp. 1001-1018; B.S. Frey/M. Kucher, History as Reflected in Capital Markets: the Case of WWII, in: Journal of Economic History 60, 2000, pp. $468-496$. 
innovation is considerably spurred by the government's wartime activities. It is widely believed, for example, that major innovations like the computer, electronic semiconductors, synthetic rubber or jet engines owe their existence (or, at least, their comparatively early introduction) to the strong military demand for these products during the Second World War and the Cold War which followed. ${ }^{17}$ In Germany, it is sometimes argued that this country's participation in the Second World War fostered R\&D, human capital formation and investment in new machinery and technology and thereby led to modernization and faster growth in the postwar period. ${ }^{18}$ Had the First World War similar long-term effects in Germany or elsewhere?

Tamás Vonyó argues against the modernization thesis. In his view, the dislocating effect of the Second World War on the German economy was much more persistent than previously believed. The impact of strategic bombing towards the geographical dislocation of productive forces has been demonstrated in his earlier work cited above. In the present volume, he shows how the division of Germany, as one of the major political consequences of the Second World War, slowed down productivity growth in West Germany for a decade because many traditional domestic suppliers of engineering and consumer products were now located behind the Iron Curtain and had therefore to be replaced by additional West German capacities. As this re-structuring of the German supplier networks took a considerable length of time, the Wirtschaftswunder of the early 1950s based primarily on factor accumulation but not on catching-up to more efficient economies. Two other articles of this volume address the short-term consequences of wartime production activities. Tetsuji Okazaki examines the development of labor productivity in Japanese coal mines during the Second World War. Based on mine-level micro data he shows that the Japanese Coal Control Association succeeded in curbing the decline of average labor productivity by re-allocating resources from inefficient to efficient mines. Taylor Jarowski and Price Fishback find that US' mobilization for Second World War had negative short-term effects on the biological standard of living. At the county level, government-sponsored expansion of armament factories increased infant mortality; at the industry level, this investment led to a higher number of industrial accidents. In the postwar years, however, Jarowski and Taylor observe quickly recovering health indicators in the US. This is in contrast to the British experience where even the long-run impact of the war on national wealth was apparently negative. ${ }^{19}$

Seen as a whole, this volume presents the methodological state of the art on the historical economics of modern warfare. Hopefully, this will inspire future research, especially on the economics of the First World War.

17 See R.R. Nelson (Ed.), Government and Technical Progress: A Cross-Industry Analysis, New York 1982.

18 See W. Abelshauser, Kriegswirtschaft und Wirtschaftswunder. Deutschlands wirtschaftliche Mobilisierung für den Zweiten Weltkrieg und die Folgen für die Nachkriegszeit, in: Vierteljahrshefte für Zeitgeschichte 47, 1999, pp. 503-538; C. Buchheim, Die Wirtschaftsentwicklung im Dritten Reich - mehr Desaster als Wunder. Eine Erwiderung auf Werner Abelshauser, in: Vierteljahrshefte für Zeitgeschichte 49, 2001, pp. 653-664.

19 See S. Broadberry/P. Howlett, The United Kingdom: 'Victory at all costs', Cambridge 1998, p. 72. 


\section{Jochen Streb/Tamás Vonyó: Historical Economics of Wars in the 20th Century}

Abstract

To stimulate projects on the historical economics of wars in the 20th century we advocate three promising research strategies by reviewing recent studies that focus on international or inter-temporal comparisons and on the economic and social consequences of war.

Keywords: Armament policy, Comparative research, War economies

JEL-Codes: H 57, L 64, N 40

Jochen Streb is Professor of Economic History in the Department of Economics at the University of Mannheim in Germany. He has contributed articles to the Economic History Review, Explorations in Economic History, the Journal of Economic History, the RAND Journal of Economics, Research Pol$i c y$, and other journals. Most recently, he has published a text book on German economic history in the 20th century (Neue deutsche Wirtschaftsgeschichte des 20. Jahrhunderts, Munich 2013, co-authored by Mark Spoerer).

Tamás Vonyó is assistant professor in economic history at Bocconi University. Until recently he held a similar position at the London School of Economics. He has completed a $\mathrm{PhD}$ in economic and social history at the University of Oxford in 2010, for which he won the dissertation prize of the International Economic History Association in 2012. His research spans the economic history of modern Germany and East Central Europe, the determinants of long-run growth, comparative industrial development, the economics of modern warfare, particularly World War II, and socialist industrialization.

Prof. Dr. Jochen Streb

Universität Mannheim

Lehrstuhl für Wirtschaftsgeschichte

Abteilung Volkswirtschaftslehre

L7, 3-5

D-68141 Mannheim

streb@uni-mannheim.de
Dr. Tamás Vonyó

Bocconi University

Department of Policy Analysis and Public Management

Via Roentgen, 1

120136 Milano

Italy

tamas.vonyo@unibocconi.it 